Bangladesh J. Plant Taxon. 20(2): 213-231, 2013 (December)

(C) 2013 Bangladesh Association of Plant Taxonomists

\title{
ANGIOSPERM FLORA OF SADAR UPAZILA OF MUNSHIGANJ DISTRICT, BANGLADESH
}

\author{
M. Oliur Rahman ${ }^{1}$, Momtaz Begum and Md. Wajib Ullah \\ Department of Botany, University of Dhaka, Dhaka 1000, Bangladesh \\ Keywords: Floristics; Angiosperms; Munshiganj; Taxonomy.
}

\begin{abstract}
Investigation to make inventory of the angiosperm species diversity in the local flora of Sadar Upazila of Munshiganj district has been made. A total of 240 taxa in 186 genera under 68 families are recognized, and enumerated citing each species with updated nomenclature, Bangla names, habit, habitat, phenology, potential value, status of occurrence in the area and voucher specimens. Of these 240 taxa, Magnoliopsida is represented by 195 taxa in 146 genera and 55 families, whereas Liliopsida by 45 taxa under 40 genera and 13 families. The local people of the area use over 50 medicinal plants as sources of medicine for their primary health care. Some species are assessed as rare to this local flora which need to be brought under conservation management for environmental sustainability of the area.
\end{abstract}

\section{Introduction}

Munshiganj Sadar, an administrative Upazila of Munshiganj district comprises an area of 160.79 sq. km., and is consisted of 9 administrative unions, namely Adhara, Bajra Jogini, Char Kewar, Char Siloi, Mahakali, Mollakandi, Panchasar, Rampal and Rekabi Bazar. The Upazila witnesses the same climatic condition as other parts of the district. The hot summer, the long rainy season and the pleasant spring-cum-winter are the main noticeable seasons prevailing in the locality. The temperature of the area fluctuates between $12.7^{\circ} \mathrm{C}$ and $33.7^{\circ} \mathrm{C}$ throughout the year. Monthly average relative humidity varies from 62 to $83 \%$, and monthly rainfall ranges from 7.7 to $373.1 \mathrm{~mm}$ throughout the year (BBS, 2011). There are three types of soil in the adjoining areas of Munshiganj Sadar Upazila, viz., heavy clayey soil that prevails over the major part of the study area, light clayey soil which occupies the second position in the area, and heavy loamy soil prevails over small area. The Upazila presents diverse habitats including scrub jungles, homesteads, char lands, riparian, roadsides and wetlands.

Over the last few decades several attempts have been made on the floristic studies in Bangladesh, particularly in the forest and protected areas (Khan and Afza, 1968; Khan and Banu, 1972; Khan and Hassan, 1984; Rahman and Hassan, 1995; Rahman and Uddin, 1997; Uddin and Rahman, 1999; Khan and Huq, 2001; Uddin and Hassan, 2004; Tutul et al., 2009, 2010; Arefin et al., 2011; Uddin and Hassan, 2012). Studies on angiosperm flora in different Upazilas of Bangladesh are limited (Islam et al., 2009; Rahman et al., 2012; Moniruzzaman et al., 2012; Rahman and Alam, 2013), however, there has been no floristic study on Munshigonj Sadar Upazila. The main objectives of the present study are to explore, identify and document the angiosperms of Munshiganj Sadar Upazila.

${ }^{1}$ Corresponding author. Email: dr_oliur@yahoo.com 


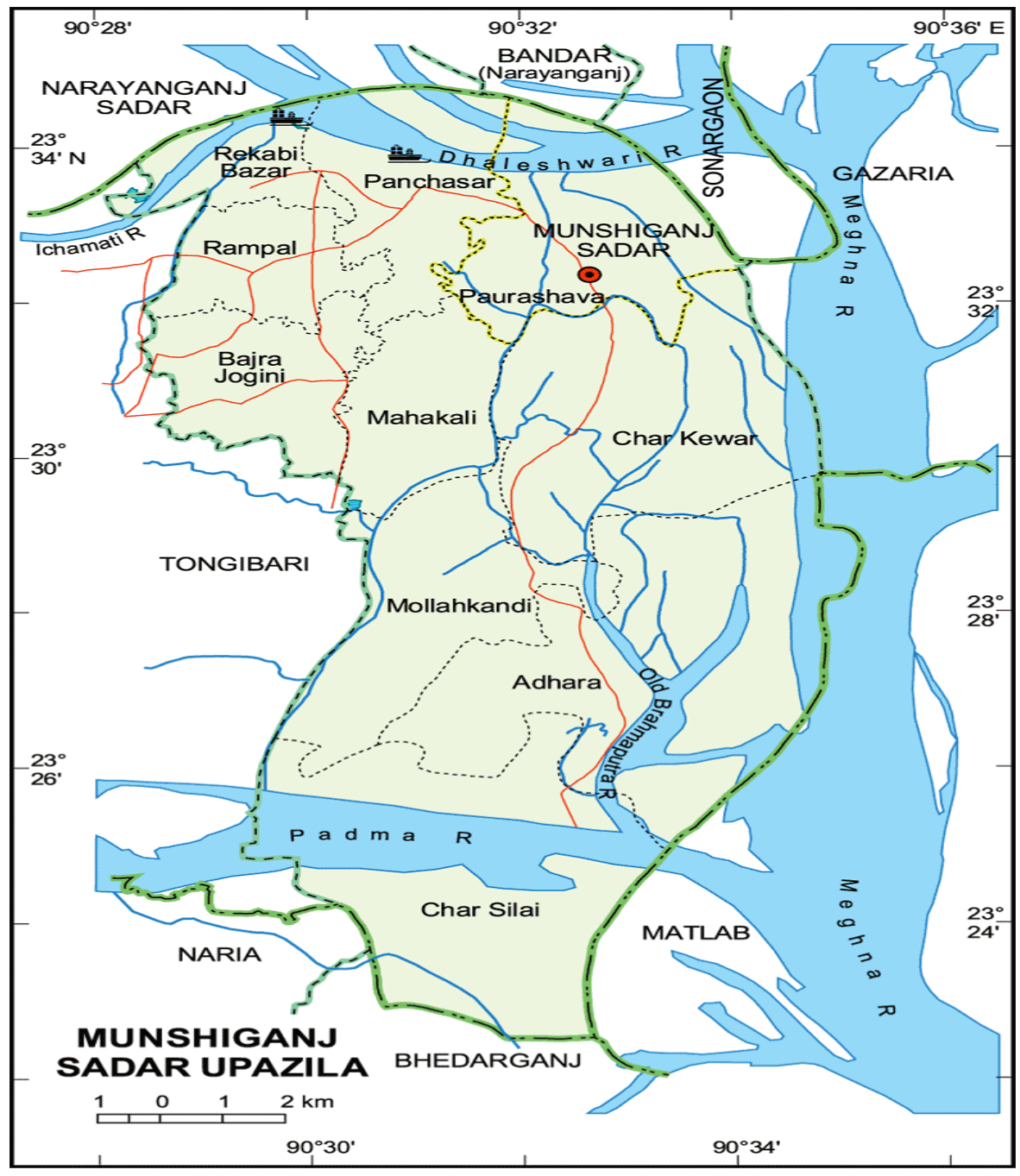

Fig. 1. Map of Munshiganj Sadar Upazila showing the sampling sites of different unions.

\section{Materials and Methods}

The work is based on fresh materials collected from Sadar Upazila of Munshiganj district from May 2012 to April 2013 (Fig. 1). Plant specimens were collected from different areas within nine unions of the Upazila and processed using standard herbarium techniques (Hyland, 1972). Collected plant specimens were critically studied, examined and identified at the department of Botany, University of Dhaka. Identification was confirmed by experts, by comparing with herbarium specimens deposited both at Dhaka University Salar Khan Herbarium (DUSH) and Bangladesh National Herbarium (DACB), and by consulting standard floras and literature, viz., Hooker (1872-1897), Prain (1903), Khan (1972-1987), Dassanayake and Fosberg (1980-1985), Khan and Rahman (1989-2002), Siddiqui et al. (2007), Ahmed et al. (2008a,b, 2009a,b,c,d) and Rashid and Rahman (2011, 2012). The identified families are arranged according to Cronquist's 
system of plant classification (Cronquist, 1981), and the genera and species under each family are arranged in an alphabetical order. Each species is furnished with updated nomenclature, Bangla names (wherever available), habit, habitat, phenology, potential value, status of occurrence in the area and voucher specimens. Voucher specimens are deposited in DUSH.

\section{Results and Discussion}

Taxonomic study of angiosperm flora of Munshiganj Sadar Upazila has revealed a total of 240 angiosperm taxa under 186 genera and 68 families (Table 1). Among them Magnoliopsida (dicotyledons) is represented by 195 taxa belonging to 146 genera and 55 families, whereas Liliopsida (monocotyledons) having comparatively less representation, only 45 species under 40 genera and 13 families. The study has revealed that Magnoliopsida constitutes about $81 \%$ of the total, while Liliopsida constitutes $19 \%$ of the total angiosperm flora. In Magnoliopsida, Asteraceae appears as the largest family comprising 13 species under 13 genera followed by Euphorbiaceae, Moraceae, Fabaceae and Mimosaceae. In Liliopsida, Poaceae is the largest family with 23 species under 19 genera followed by Araceae, Arecaceae, Commelinaceae and Cyperaceae. In the study area the number of species in the families varies from 1 to 23. Out of 68 families recorded, each of 27 families is represented by a single species. Five largest genera of dicotyledons are Ficus (7 species), Amaranthus (4 species), Persicaria (4 species), Syzygium (4 species) and Ipomoea (3 species); while that of monocotyledons are Commelina, Echinochloa, Leptochloa and Brachiaria, each with 2 species.

Among the total flora herbs are represented by 141 taxa, shrubs by 26 and trees by 73 . Out of 68 families recorded, 10 dominant families are Poaceae, Asteraceae, Euphorbiaceae, Moraceae, Fabaceae, Mimosaceae, Solanaceae, Myrtaceae, Malvaceae and Rubiaceae. The dominant families along with the number of species and genera are shown in Figure 2. These ten families comprise 105 species that represent about $44 \%$ of the total species identified. The remaining 58 families with a total 135 species represent $56 \%$ of the total.

One of the important phenomena of the study area is that the Sadar Upazila presents char land. The major angiosperms of the char are Alternanthera paronychyoides St. Hill., A. sessilis (L.) R. Br. ex. Roem \& Schult., Brassica napus L. (cultivated), Chenopodium album L., Citrullus lanatus (Thub.) Matsumura \& Nakai (cultivated), Cyanotis cristata (L.) D. Don, Glinus oppositifolius (L.) A. DC., Gnaphalium luteo-album L., Grangea maderaspatana (L.) Poir. and Oxalis corniculata L. The common riparian plants are Brachiaria decumbens Stapf, Coix aquatica Roxb., Crateva magna (Lour.) DC., Ipomoea fistulosa Mart. ex Choisy, Operculina turpethum (L.) S. Manso, Persicaria barbata (L.) Hara, P. lapathifolia (L.) S. F. Gray, Phragmites karka (Retz.) Trin. ex Steud. and Saccharum spontaneum L. The common roadside plants include Albizia lebbeck (L.) Benth. \& Hook., A. procera (Roxb.) Benth., Commelina benghalensis L., Euphorbia hirta L., Ficus benghalensis L., F. racemosa L., Sida acuta Burm. f. and Spilanthes calva DC. The upazila provides several aquatic habitats including ponds, beels, jheels, rivers, etc. which offer luxuriant formation of angiosperm flora. Some common aquatic angiosperms are Barringtonia acutangula (L.) Gaertn., Eichhornia crassipes (Mart.) Solms, Enhydra fluctuans Lour., Hygrorhyza aristata (Retz.) Nees, Ipomoea aquatica Forssk., Lemna perpusilla Torrey, Ludwigia adscendens (L.) Hara, L. hyssopifolia (G. Don) Exell Apud A. \& R. Fern., Nymphaea nouchali Burm. f., N. pubescens Willd., N. rubra Roxb. et Andr., Nymphoides hydrophylla (Lour.) O. Kuntze, Ottelia alismoides (L.) Pers., Panicum paludosum Roxb., Persicaria barbata (L.) Hara, P. lanata (Roxb.) Hassan, P. orientalis (L.) Spach, Phragmites karka (Retz.) Trin. ex Steud., Pistia stratiotes L. and Vallisneria spiralis L. 


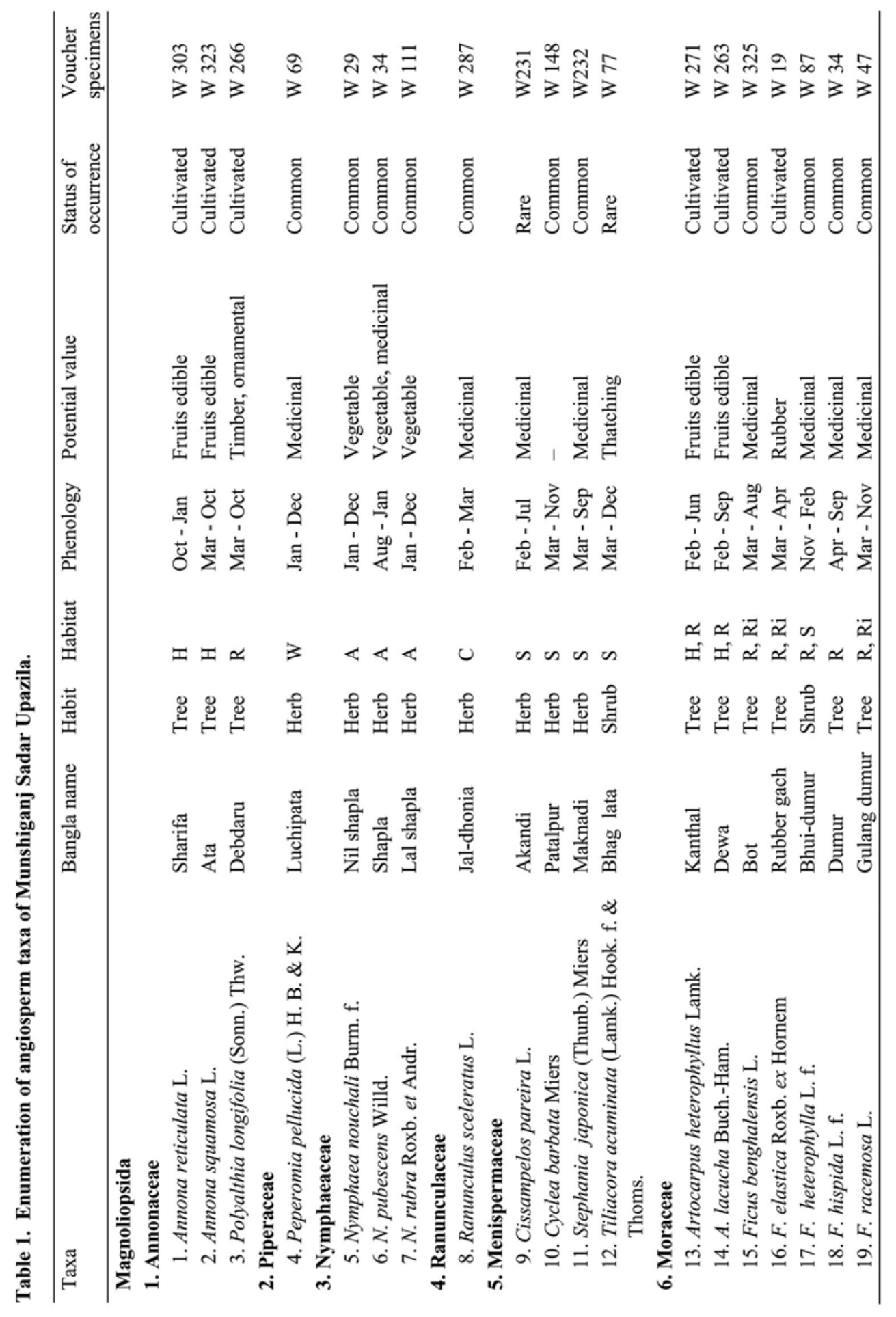




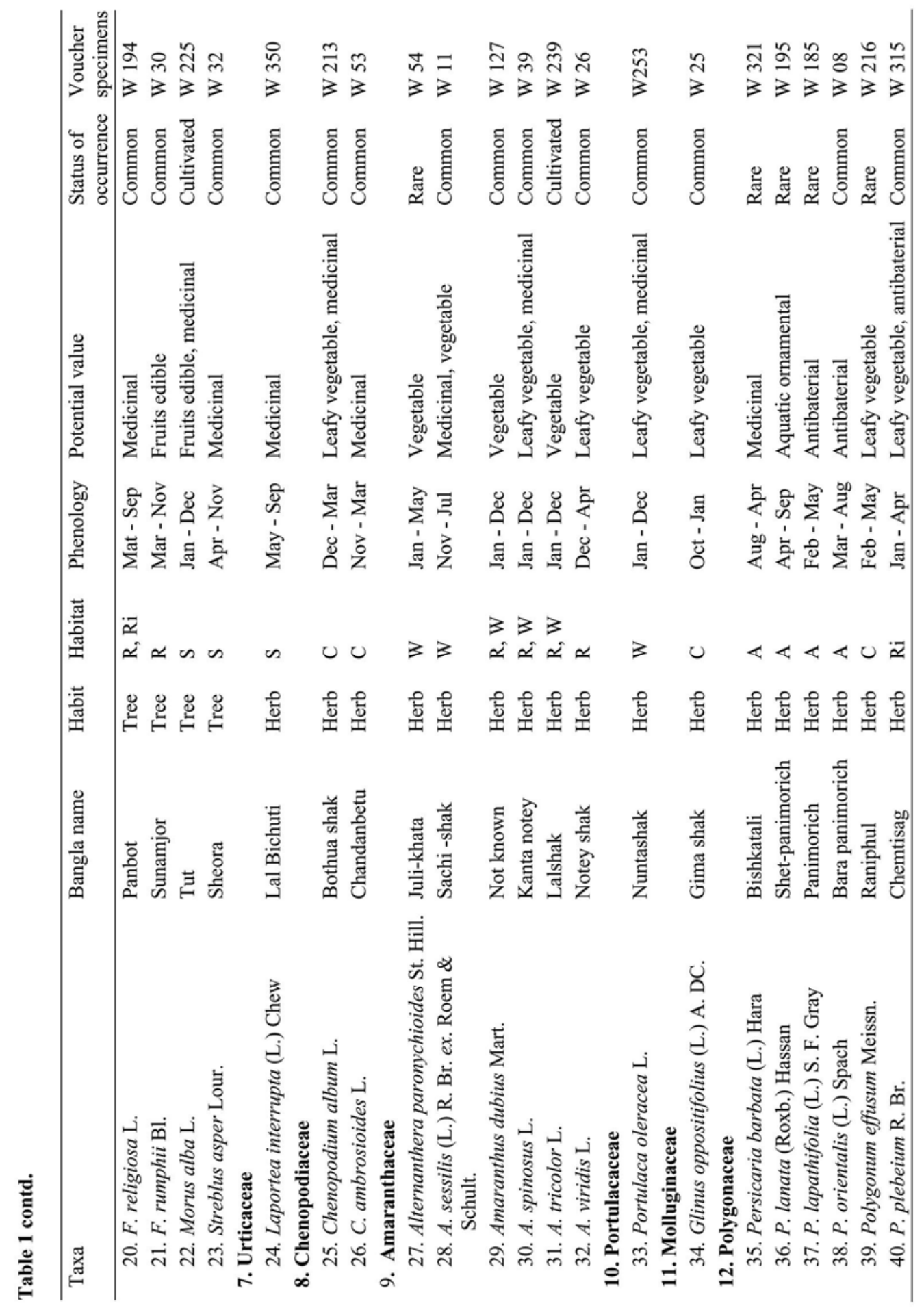




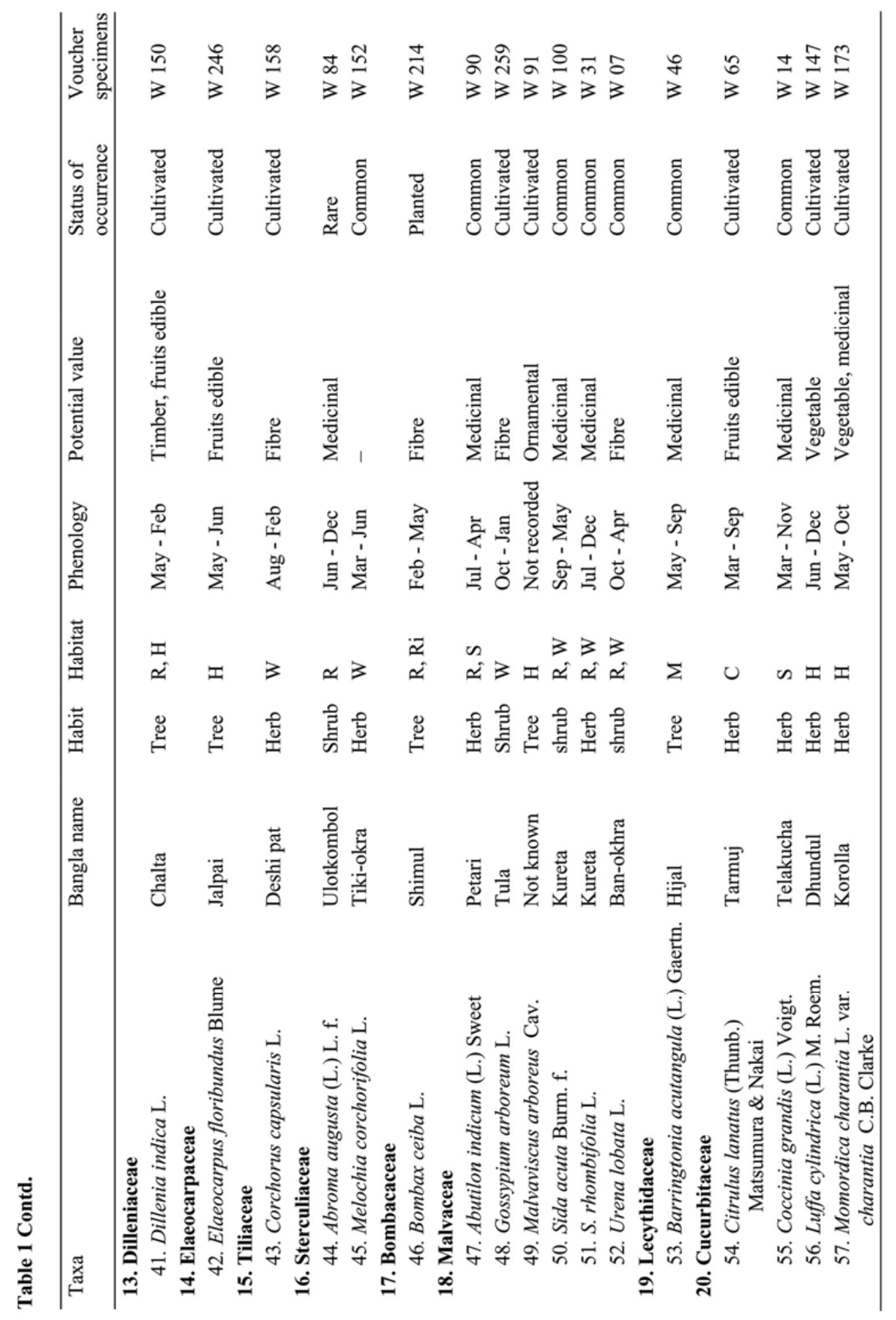




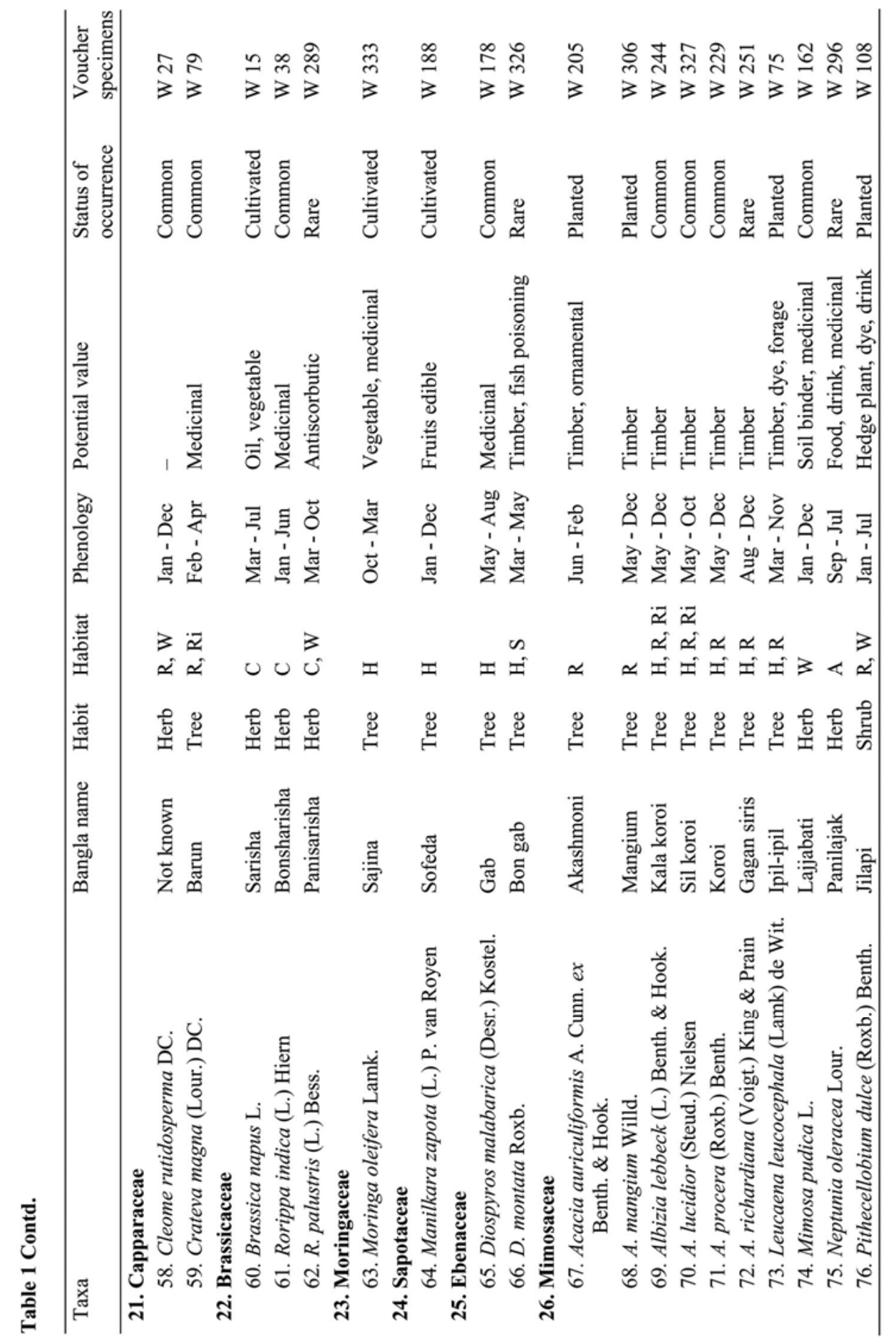




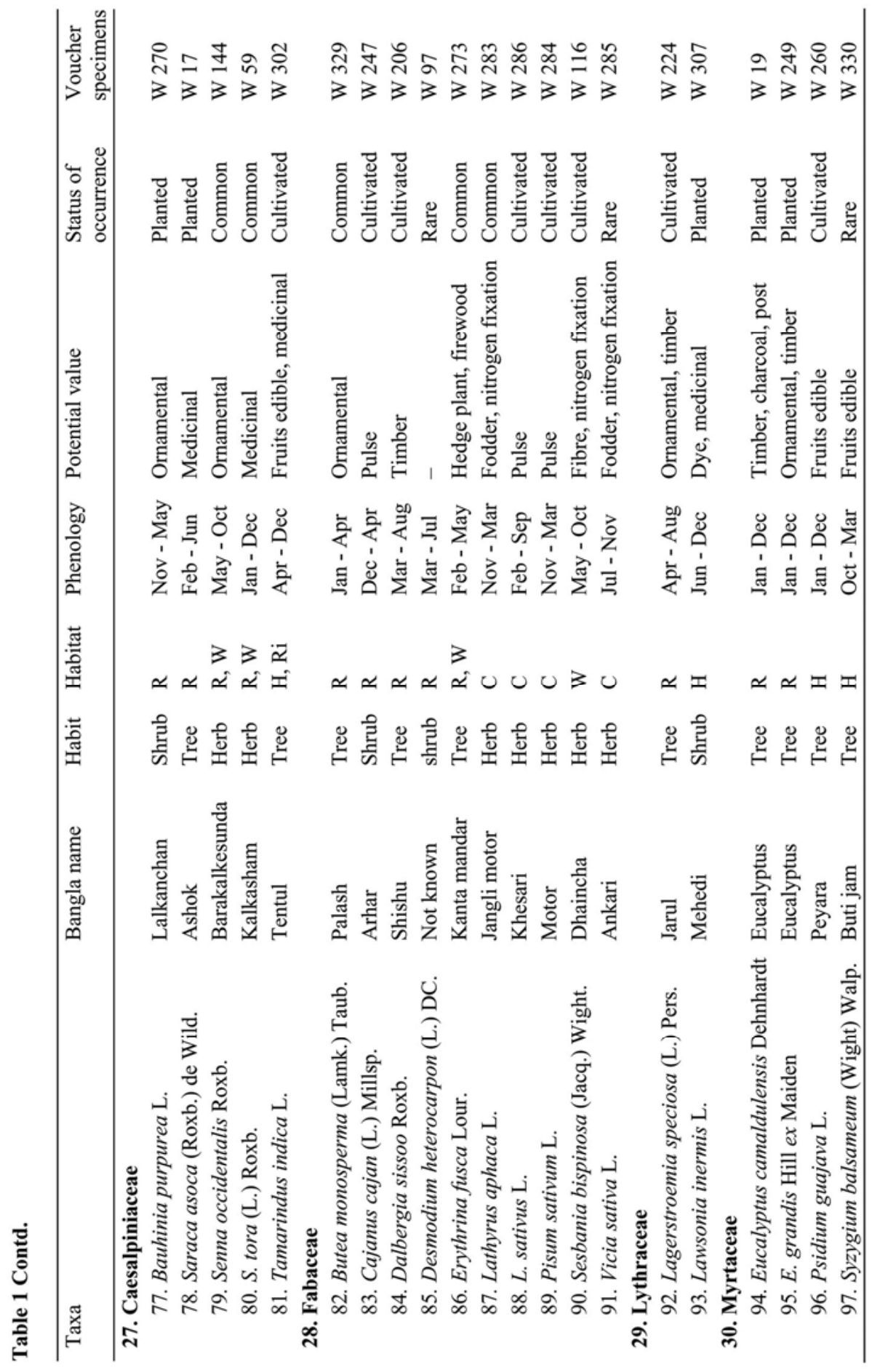




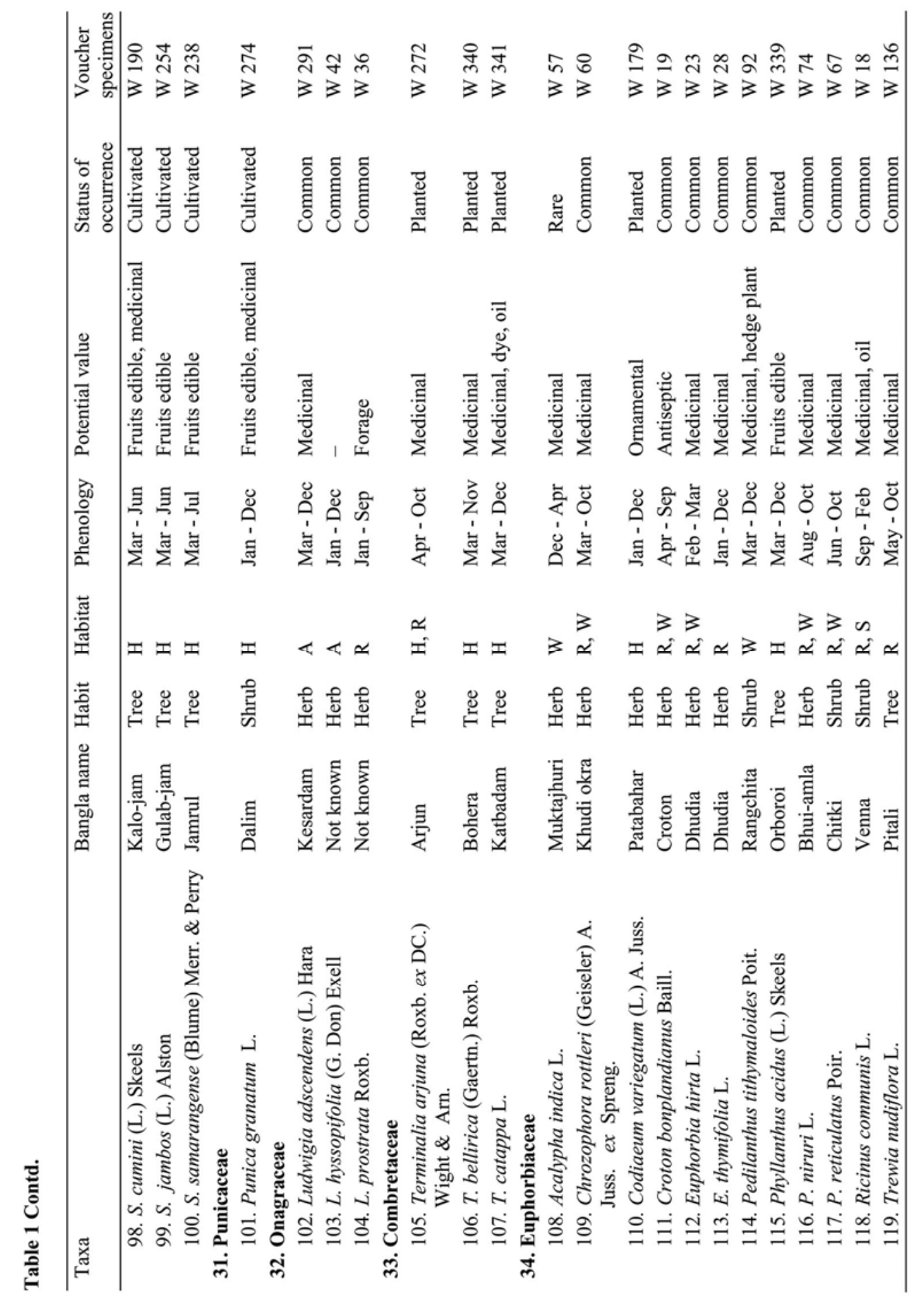




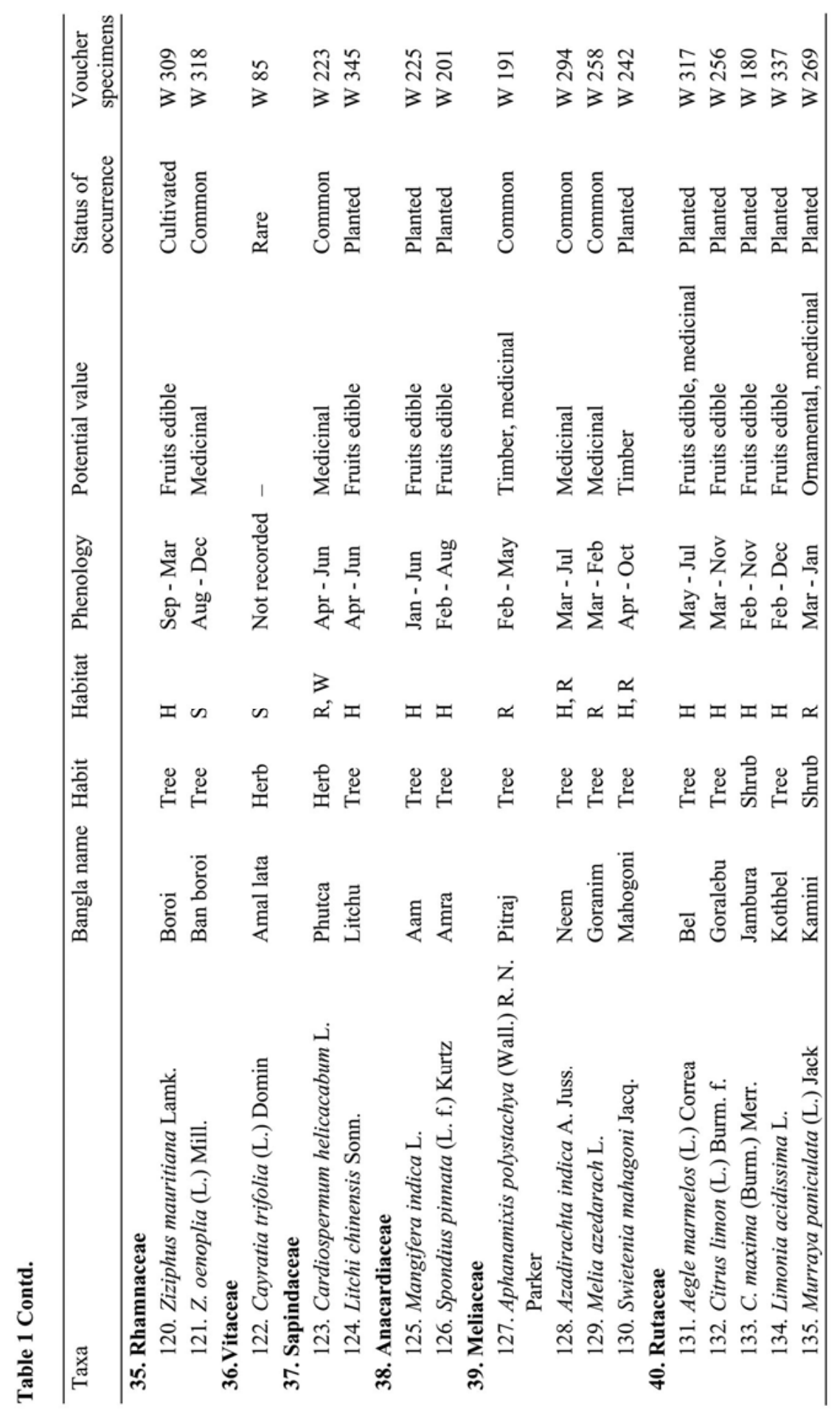




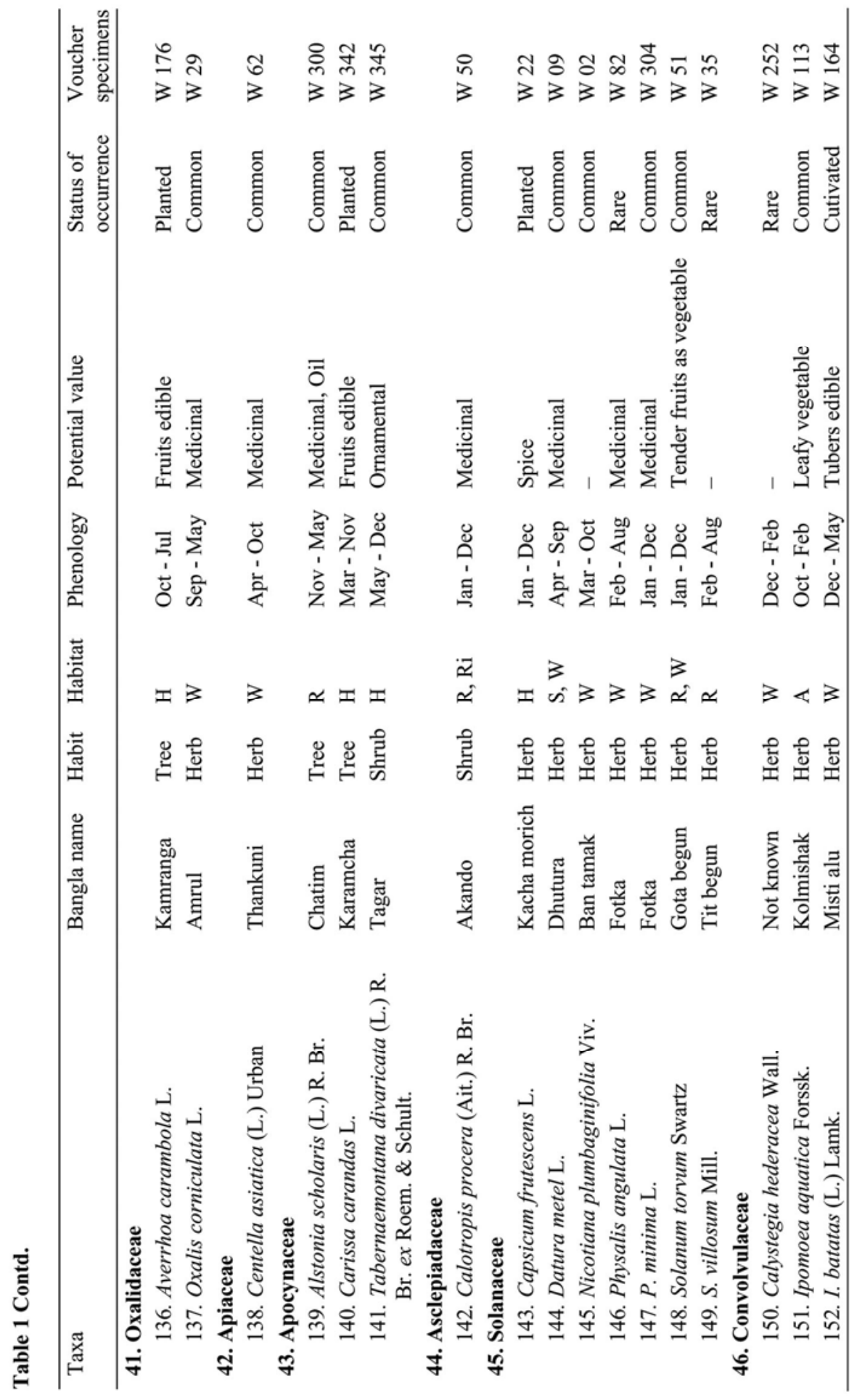




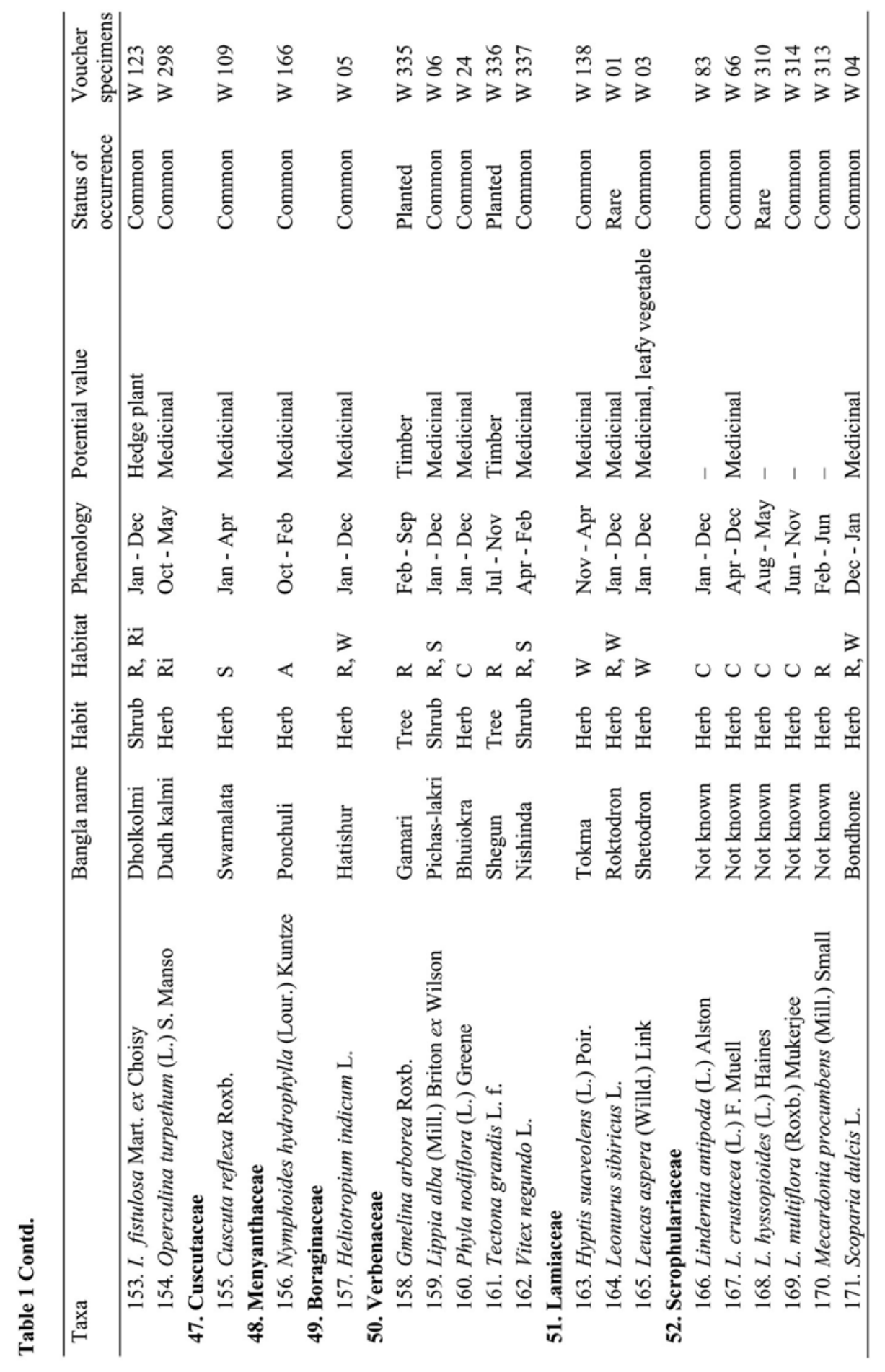




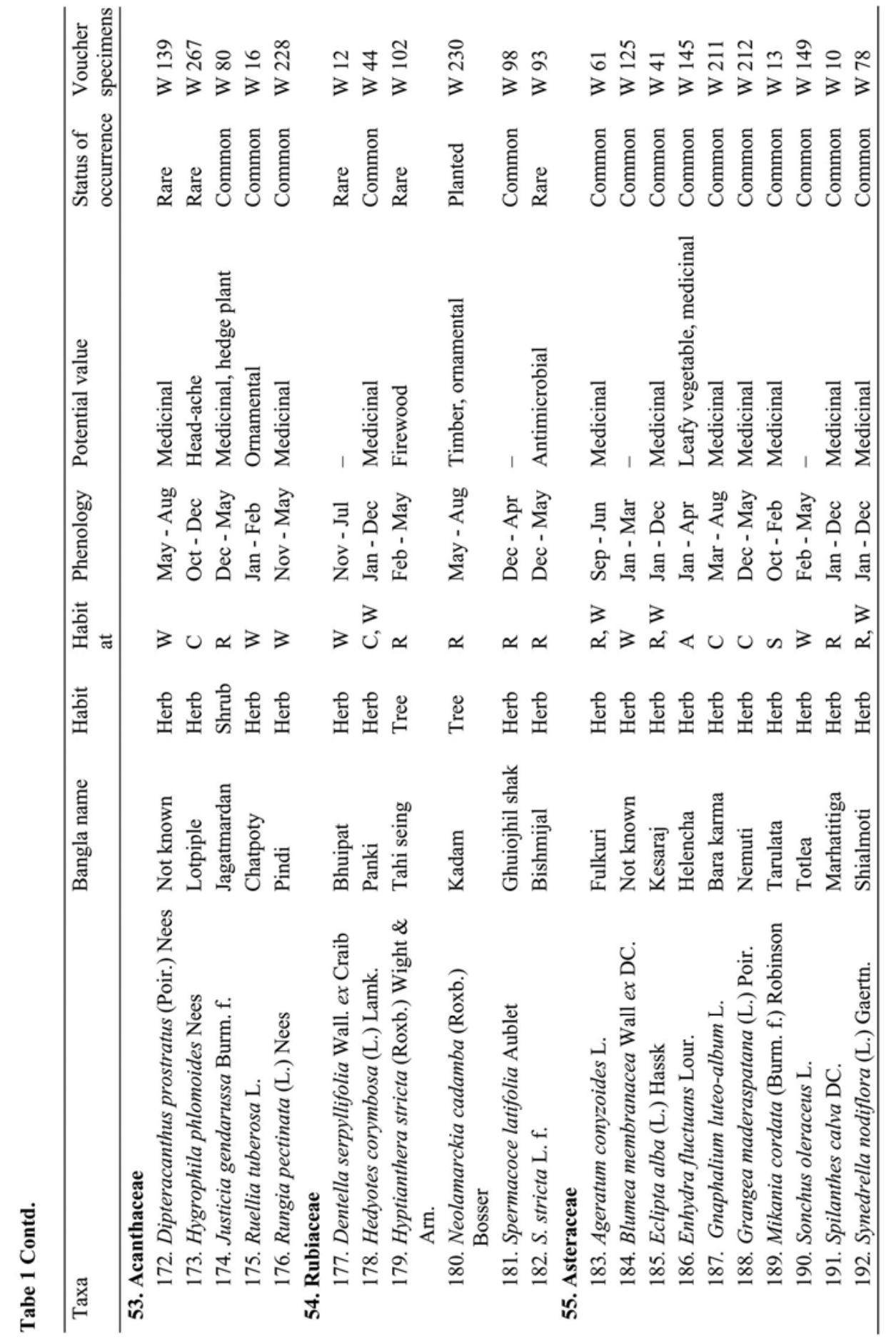




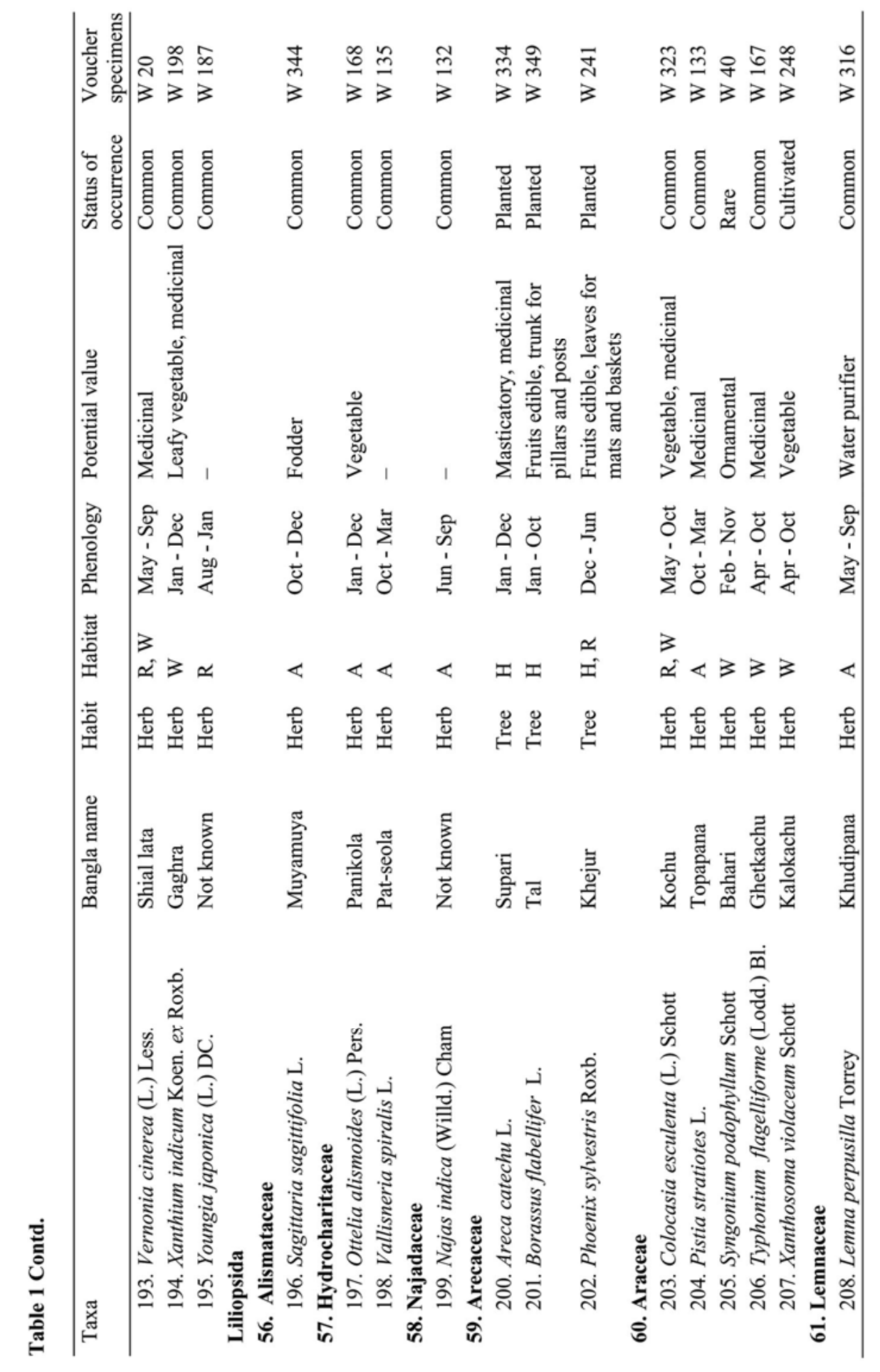




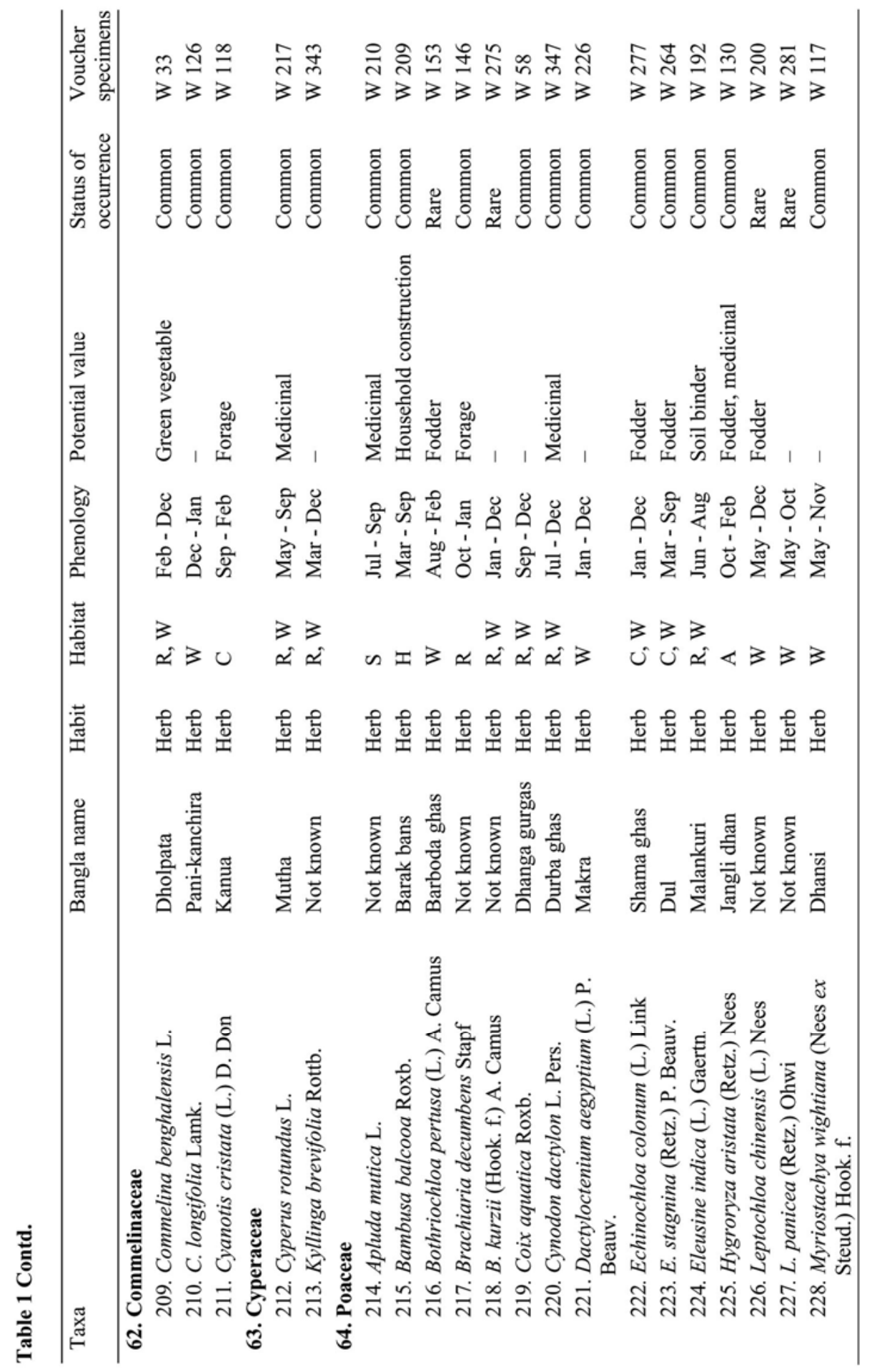




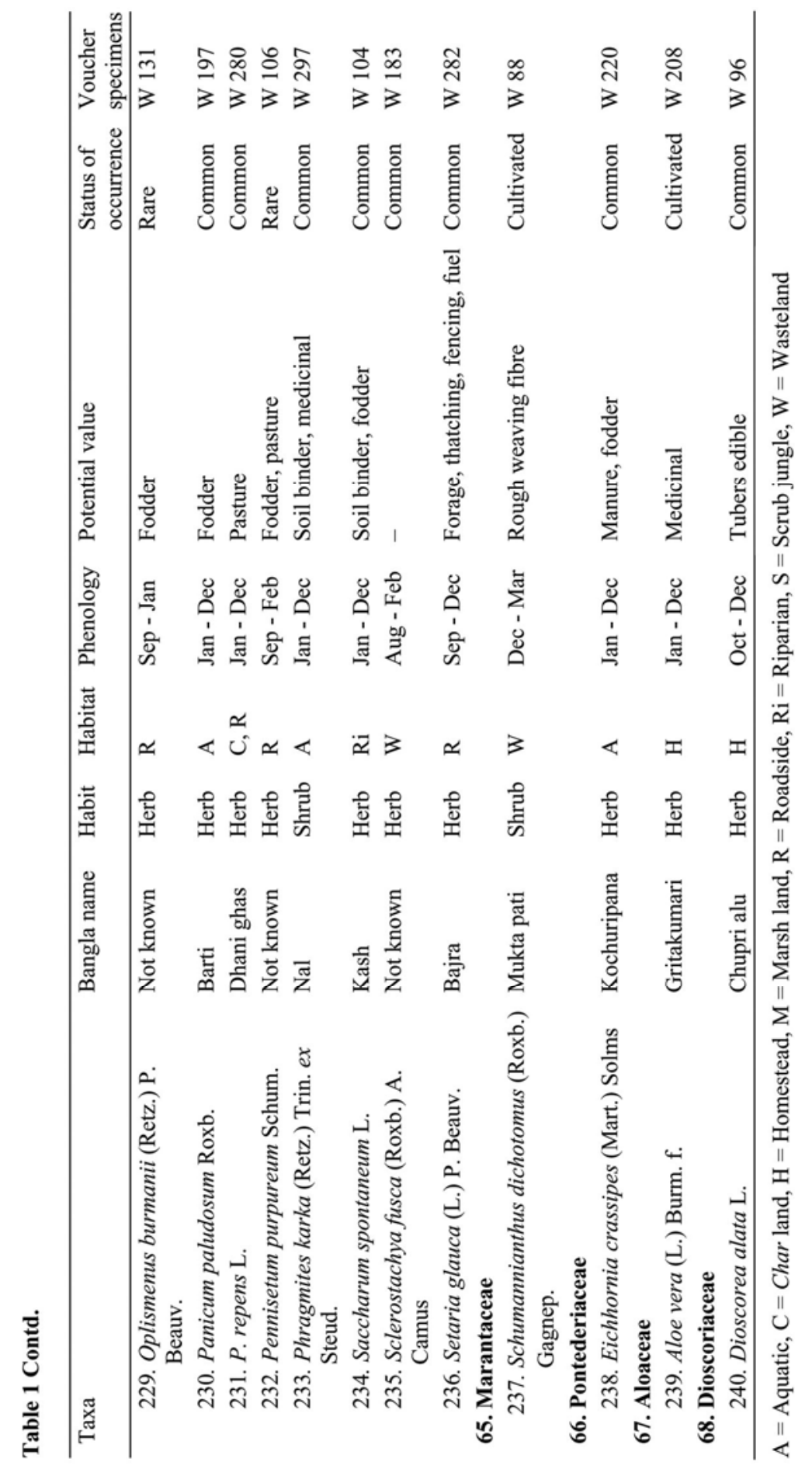




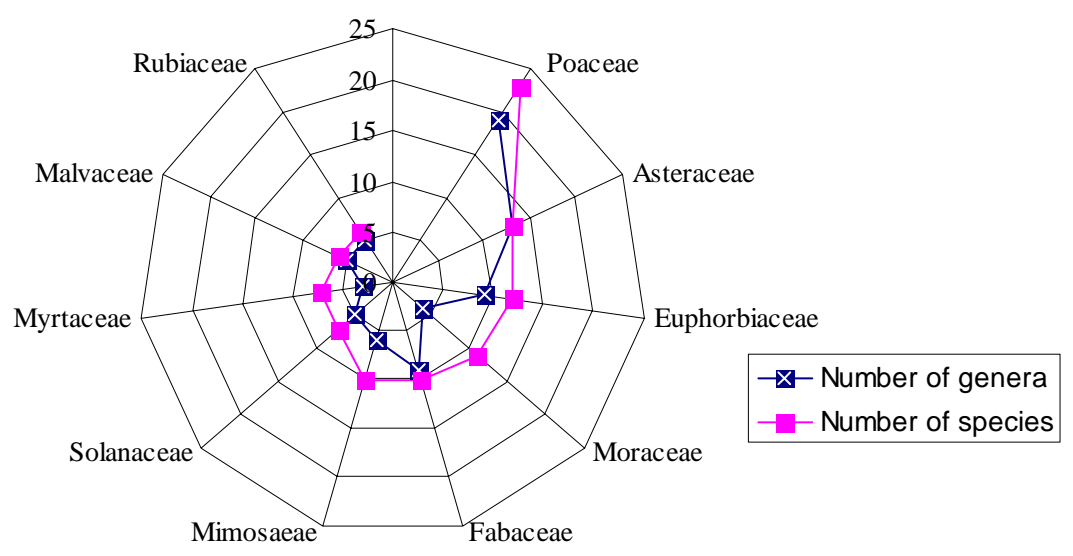

Fig. 2. Raddar diagram showing the 10 largest families in Munshiganj Sadar Upazila.

The present study identifies over 50 medicinal plants used by the local people of Munshiganj Sadar Upazila for their primary health care. They use the medicinal plants for treatment of several common diseases including dysentery, diarrhoea, diabetes, fever, cold and cough, asthma, ulcer, constipation, abdominal pain, indigestion, gonorrhoea, jaundice, stop bleeding, piles, scabies and rheumatic pain. Some of the important medicinal plants used by the local people are Abroma augusta (L.) L. f., Acalypha indica L., Aloe vera (L.) Burm. f., Alstonia scholaris (L.) R. Br., Azadirachta indica A. Juss., Calotropis procera (Ait.) R. Br., Centella asiatica (L.) Urban, Coccinia grandis (L.) Voigt., Mikania cordata (Burm. f.) Robinson, Phyllanthus niruri L., Saraca asoca (Roxb.) Willd., Terminalia arjuna (Roxb. ex DC.) Wight \& Arn. and Vitex negundo L. Apart from medicinal uses some species are used by local people in their religious festivals, viz., Aegle marmelos (L.) Correa, Areca catechu L., Bauhinia purpurea L., Butea monosperma (Lamk.) Taub. and Cynodon dactylon (L.) Pers. The study has also identified some rare plants in Munshiganj sadar upazila, i.e. Alternanthera paronychyoides St. Hill., Diospyros montana Roxb., Dipteracanthus prostratus (Poir.) Nees, Operculina turpethum (L.) S. Manso, Persicaria lanata (Roxb.) Hassan and Tiliacora acuminata (Lamk.) Hook. f. \& Thoms.

Though the study area has a moderately rich resource of angiospermic flora, it witnesses some threats which might cause this resource to extinct. Observations and group discussion with local people during field works resulted in identifying some major threats which include urbanization, modern agriculture, lack of awareness, exotic plantation and river erosion. Therefore, efforts should be undertaken to safeguard the plants through ex situ and in situ approaches, public awareness should be built up, and protection of habitats of the species should be ensured.

\section{Acknowledgement}

We thank Prof. Md. Abul Hassan of the Department of Botany, University of Dhaka for his help and cooperation during the course of this study.

\section{References}

Ahmed, Z.U., Begum, Z.N.T., Hassan, M.A., Khondker, M., Kabir, S.M.H., Ahmad, M., Ahmed, A.T.A., Rahman, A.K.A. and Haque, E.U. (Eds) 2008a. Encyclopedia of Flora and Fauna of Bangladesh, Vol. 6. Angiosperms: Dicotyledons (Acanthaceae - Asteraceae). Asiatic Society of Bangladesh, Dhaka, pp. 1408. 
Ahmed, Z.U., Hassan, M.A., Begum, Z.N.T., Khondker, M., Kabir, S.M.H., Ahmad, M., Ahmed, A.T.A., Rahman, A.K.A. and Haque, E.U. (Eds) 2008b. Encyclopedia of Flora and Fauna of Bangladesh, Vol. 12. Angiosperms: Monocotyledons (Orchidaceae - Zingiberaceae). Asiatic Society of Bangladesh, Dhaka, pp. 1-552.

Ahmed, Z.U., Hassan, M.A., Begum, Z.N.T., Khondker, M., Kabir, S.M.H., Ahmad, M., Ahmed, A.T.A., Rahman, A.K.A. and Haque, E.U. (Eds) 2009a. Encyclopedia of Flora and Fauna of Bangladesh, Vol. 7. Angiosperms: Dicotyledons (Balsaminaceae - Euphorbiaceae). Asiatic Society of Bangladesh, Dhaka, pp. 1-546.

Ahmed, Z.U., Hassan, M.A., Begum, Z.N.T., Khondker, M., Kabir, S.M.H., Ahmad, M., Ahmed, A.T.A., Rahman, A.K.A. and Haque, E.U. (Eds) 2009b. Encyclopedia of Flora and Fauna of Bangladesh, Vol. 8. Angiosperms: Dicotyledons (Fabaceae - Lythraceae). Asiatic Society of Bangladesh, Dhaka, pp. 1-478.

Ahmed, Z.U., Hassan, M.A., Begum, Z.N.T., Khondker, M., Kabir, S.M.H., Ahmad, M. and Ahmed, A.T.A. (Eds) 2009c. Encyclopedia of Flora and Fauna of Bangladesh, Vol. 9. Angiosperms: Dicotyledons (Magnoliaceae - Punicaceae). Asiatic Society of Bangladesh, Dhaka, pp. 1-488.

Ahmed, Z.U., Hassan, M.A., Begum, Z.N.T., Khondker, M., Kabir, S.M.H., Ahmad, M., and Ahmed, A.T.A. (Eds) 2009d. Encyclopedia of Flora and Fauna of Bangladesh, Vol. 10. Angiosperms: Dicotyledons (Ranunculaceae - Zygophyllaceae). Asiatic Society of Bangladesh, Dhaka, pp. 1-580.

Arefin, M.K., Rahman, M.M., Uddin, M.Z. and Hassan, M.A. 2011. Angiosperm flora of Satchari National Park, Habiganj, Bangladesh. Bangladesh J. Plant Taxon. 18(2): 117-140.

BBS (Bangladesh Bureau of Statistics) 2011. Monthly Statistical Bulletin. Statistics Division, Ministry of Planning, Government of the People's Republic of Bangladesh.

Cronquist, A. 1981. An Integrated System of Classification of Flowering Plants. Columbia Univ. Press, New York.

Dassanayake, M.D. and Fosberg, F.R. (Eds) 1980-1985. A Revised Handbook to the Flora of Ceylon, Vols. 1-5. Amerind Publishing Co. Pvt. Ltd., New Delhi.

Hooker, J.D. 1872-1897. The Flora of British India, Vols. 1-7. L. Reeve \& Co. Ltd., Kent, England.

Hyland, B.P.M. 1972. A technique for collecting botanical specimens in rain forest. Flora Malesiana Bulletin 26: 2038-2040.

Islam, M.R., Uddin, M.Z. and Hassan, M.A. 2009. An assessment of the angiospermic flora of Ramgarh upazila of Khagrachari district, Bangladesh. Bangladesh J. Plant Taxon. 16(2): 115-140.

Khan, M.S. (Ed.) 1972-1987 Flora of Bangladesh. Nos. 1-39. Bangladesh National Herbarium and Bangladesh Agricultural Research Council, Dhaka.

Khan, M.S. and Afza, S.K. 1968. A taxonomic report on the angiospermic flora of Teknaf and St. Martin's Island. Dhaka Univ. Studies, Part B. 16: 35-37.

Khan, M.S. and Banu, F. 1972. A taxonomic report on the angispermic flora of Chittagong Hill Tracts-2. J. Asiatic Soc. Bangladesh 17(2): 63-68.

Khan, M.S. and Hassan, M.A. 1984. A taxonomic report on the angiospermic flora of St. Martin's Island. Dhaka Univ. Studies, Part B. 32(1): 76-78.

Khan, M.S. and Huq, A.M. 2001. The vascular flora of Chunati Wildlife Sanctuary in south Chittagong, Bangladesh. Bangladesh J. Plant Taxon. 8(1): 47-64.

Khan, M.S. and Rahman, M.M. (Eds) 1989-2002. Flora of Bangladesh. Nos. 40-53. Bangladesh National Herbarium and Bangladesh Agricultural Research Council, Dhaka.

Moniruzzaman, M., Hassan, M.A., Rahman, M.M., Layla, S. and Islam, M.R. 2012. A preliminary checklist of the angiospermic flora of Daulatpur Upazila in Kushtia district, Bangladesh. J. Asiat. Soc. Bangladesh, Sci. 38(1): 53-65.

Prain, D. 1903. Bengal Plants, Vols. 1-2. Botanical Survey of India, Calcutta.

Rahman, M.A. and Uddin, S.B. 1997. Assessment of plant diversity of Sitakunda in Chittagong. Bangladesh J. Plant Taxon. 4(1): 17-36.

Rahman, M.O. and Hassan, M.A. 1995. Angiospermic flora of Bhawal National Park, Gazipur (Bangladesh). Bangladesh J. Plant Taxon. 2(1\&2): 47-79. 
Rahman, M.O. and Alam, M.T. 2013. A taxonomic study on the angiosperm flora of Trishal upazila, Mymensingh. Dhaka Univ. J. Biol. Sci. 22(1): 63-74.

Rahman, M.O., Antara, R.T., Begum, M. and Hassan, M.A. 2012. Floristic diversity of Dhamrai upazila of Dhaka, Bangladesh with emphasis on medicinal plants. Bangladesh J. Bot. 41(1): 71-85.

Rashid, M.E. and Rahman, M.A. 2011. Updated nomenclature and taxonomic status of the plants of Bangladesh included in Hook. f., The Flora of British India: Volume-I. Bangladesh J. Plant Taxon. 18(2): 177-197.

Rashid, M.E. and Rahman, M.A. 2012. Updated nomenclature and taxonomic status of the plants of Bangladesh included in Hook. f., The Flora of British India: Volume-II. Bangladesh J. Plant Taxon. 19(2): 173-190.

Siddiqui, K.U., Islam, M.A., Ahmed, Z.U., Begum, Z.N.T., Hassan, M.A., Khondker, M., Rahman, M.M., Kabir, S.M.H., Ahmad, M., Ahmed, A.T.A., Rahman, A.K.A. and Haque, E.U. (Eds) 2007. Encyclopedia of Flora and Fauna of Bangladesh, Vol. 11. Angiosperms: Monocotyledons (Agavaceae Najadaceae). Asiatic Society of Bangladesh, Dhaka, pp. 1-399.

Tutul, E., Uddin, M.Z., Rahman, M.O. and Hassan, M.A. 2009. Angiospermic flora of Runctia Sal forest, Bangladesh. I. Liliopsida (Monocots). Bangladesh J. Plant Taxon. 16(1): 83-90.

Tutul, E., Uddin, M.Z., Rahman, M.O. and Hassan, M.A. 2010. Angiospermic flora of Runctia Sal forest, Bangladesh. II. Magnoliopsida (Dicots). Bangladesh J. Plant Taxon. 17(1): 33-53.

Uddin, M.Z. and Hassan, M.A. 2004. Flora of Rema-Kalenga Wildlife Sanctuary, IUCN Bangladesh Country Office, Dhaka, Bangladesh.

Uddin, S.B. and Rahman, M.A. 1999. Angiospermic flora of Himchari National Park, Cox’s Bazar, Bangladesh. Bangladesh J. Plant Taxon. 6(1): 31-68.

Uddin, S.N. and Hassan, M.A. 2012. Angiosperm flora of Rampahar Reserve Forest under Rangamati district in Bangladesh. I. Liliopsida (Monocots). Bangladesh J. Plant Taxon. 19(1): 37-44.

(Manuscript received on 3 June 2013; revised on 5 November 2013) 